\title{
Do non-steroidal anti-inflammatory drugs or smoking predispose to Helicobacter pylori infection?
}

\author{
D.G. Maxton, E.D. Srivastava, P.J. Whorwell and D.M. Jones \\ Departments of Medicine and Microbiology, University Hospital of South Manchester, West Didsbury, \\ Manchester M20 8LR, UK.
}

\begin{abstract}
Summary: Susceptibility to Helicobacter pylori infection is a poorly understood phenomenon. This study was undertaken to establish whether either smoking or chronic non-steroidal anti-inflammatory drug (NSAID) consumption might in some way predispose to $H$. pylori infection and hence lead to peptic ulceration. Serological evidence of $H$. pylori infection was assessed in 100 consecutive subjects receiving NSAIDs without any evidence of gastrointestinal upset and 100 matched controls. All subjects had a full assessment of their smoking habits. Sixty-three per cent of patients taking NSAIDs compared to $51 \%$ of controls had evidence of $\boldsymbol{H}$. pylori infection (NS). Smoking habit also had no effect on $\boldsymbol{H}$. pylori colonization. The ulcerogenic potential of NSAIDs and smoking does not appear to be mediated via a predisposition to $\boldsymbol{H}$. pylori infection.
\end{abstract}

\section{Introduction}

There is considerable interest in the role of Helicobacter pylori infection $(H$. pylori, formerly Campylobacter pylori) in the induction of upper gastrointestinal inflammation and peptic ulceration. ${ }^{1-7}$ However, the reason why colonization with this organism occurs in some people and not others has received relatively little attention.

The well documented association of nonsteroidal anti-inflammatory drug (NSAID) therapy with gastritis and peptic ulceration is generally assumed to be a consequence of interference with prostaglandin metabolism..$^{8-11}$ With regard to smoking, a variety of mechanisms have been advanced to explain why this habit may predispose to gastric and duodenal ulceration. ${ }^{12-14}$ However, the possibility that NSAIDs or smoking might in some way facilitate $H$. pylori colonization has not been previously investigated.

It was the purpose of this study to establish whether regular NSAID consumption or smoking are associated with serological evidence of $H$.pylori infection thereby explaining the link between these factors and upper gastrointestinal pathology.

\section{Subjects and methods}

\section{Subjects}

One hundred consecutive patients receiving NSAIDs attending orthopaedic and fracture clinics

Correspondence: P.J. Whorwell, B.Sc., M.D., M.R.C.P. Accepted: 1 May 1990 without any symptoms or history of upper gastrointestinal disease were studied. All patients had to have been on NSAIDs for at least 3 months and patients with inflammatory arthritis were excluded. There were 62 women and 38 men in the study group. Age ranged from 18-86 years with a mean of 61.3 years. Thirty-two were cigarette smokers and 68 non-smokers. One hundred control subjects matched for age, sex and also smoking habits attending the same clinic were also studied. None of the control group had a history of NSAID usage or upper gastrointestinal symptoms.

\section{Laboratory methods}

Sera were tested for IgG antibodies to $H$. pylori by ELISA using a multistrain pool of whole organisms. ${ }^{15}$ This has been shown to correlate very highly with evidence of $H$. pylori infection obtained by histological specimens. ${ }^{15,16}$

McNemar's test was used to compare proportions from matched data and the chi-square test used to compare independent proportions. T-tests were carried out for comparison of means, together with logarithmic transformation where appropriate.

\section{Results}

Overall, 114 of the 200 people tested were serologically positive for $H$. pylori. The study confirmed previous observations of increasing colonization of $H$.pylori with increasing age. Thus the mean age of $H$. pylori positive patients was 63.5 
years against 58.2 years for those with no evidence of infection $(P=0.005)$.

Sixty-three per cent of NSAID users were positive for antibody to $H$. pylori compared to $51 \%$ of controls (Table I). This difference is not significant. Further, there was no correlation between antibody status and length of time on NSAIDs. The mean length of time patients had received NSAID was 18.2 months for $H$. pylori positive subjects compared with 15.5 months for $H$. pylori negative $(P=0.43$, not significant).

Analysis of the data for an independent effect of either smoking habit or sex was negative. Thus similar numbers of smokers $(56 \%)$ and nonsmokers $(57 \%)$ were $H$. pylori positive and there was also no difference between the proportion of men $(60 \%)$ and women $(55 \%)$ with serological evidence of infection.

\section{Discussion}

The results of this study suggest that neither smoking nor the consumption of NSAIDs predisposes to infection with $H$. pylori. In addition, the two factors in conjunction have no effect and the length of time NSAIDs are taken for is not relevant.

An important feature of this study was that only patients and controls without any gastrointestinal symptoms were investigated. This was done deliberately to exclude, as far as possible, patients who might be colonized with $\boldsymbol{H}$. pylori for other reasons and raise problems of cause and effect. Thus the study is more likely to reflect the true and independent effect of smoking and NSAID consumption on $\boldsymbol{H}$. pylori colonization.

The inclusion of some patients with silent upper gastrointestinal pathology cannot be avoided but it was not felt ethically justified to perform endoscopies particularly on symptomless control subjects.

The reason why some individuals become colonized by $H$. pylori remains unknown. This important aspect in the understanding of the role of this organism in the pathogenesis of peptic ulceration requires further investigation. However, it is clear that smoking and NSAID consumption do not influence this phenomenon.

Table I Percentage of subjects positive for $H$. pylori

\begin{tabular}{|c|c|c|}
\hline$\%$ subjects $\mathrm{H}$. pylori-positive & $\%$ Difference & $(95 \% C I)$ \\
\hline $\begin{array}{cc}\begin{array}{c}\text { NSAID users } \\
(n=100)\end{array} & \begin{array}{c}\text { Controls } \\
(n=100) \\
63\end{array} \\
\left(\chi^{2}=2.63, P=0.105, \mathrm{NS}\right) & \end{array}$ & $12 \%$ & $(-2 \%$ to $26 \%)$ \\
\hline $\begin{array}{lc}\begin{array}{c}\text { Smokers } \\
(n=64) \\
56\end{array} & \begin{array}{c}\text { Non-smokers } \\
(n=136) \\
57\end{array} \\
\left(\chi^{2}=0.02, P=0.88, \mathrm{NS}\right) & \end{array}$ & $-1 \%$ & $(-16 \%$ to $14 \%)$ \\
\hline $\begin{array}{lc}\begin{array}{l}\text { Male } \\
(n=76)\end{array} & \begin{array}{c}\text { Female } \\
(n=124)\end{array} \\
60 & 55 \\
\left(\chi^{2}=0.62, P=0.43, \mathrm{NS}\right) & \end{array}$ & $5 \%$ & $(-9 \%$ to $19 \%)$ \\
\hline
\end{tabular}

\section{References}

1. Warren, J.R. \& Marshall, B.J. Unidentified curved bacilli on gastric epithelium in active chronic gastritis. Lancet 1983, i: 1273-1275.

2. Marshall, B.J., McGechie, D.B., Rogers, P.A. \& Glancy, R.J. Pyloric campylobacter infection and gastroduodenal disease. Med J Aust 1985, 142: 439-444.

3. Niemala, S., Kartunnen, T. \& Lehtola, J. Campylobacter like organism in patients with gastric ulcer. Scand J Gastroenterol 1987, 22: 487-490.

4. Goodwin, C.S., Armstrong, J.A. \& Marshall, B.J. Campylobacter pyloridis, gastritis and peptic ulceration. $J$ Clin Pathol 1986, 39: 353-365.

5. Bartlett, J.G. Campylobacter pylori. Fact or Fancy? Gastroenterology, 1988, 94: 229-238.
6. Graham, D.Y. \& Klein, P.D. Campylobacter pyloridis gastritis; the past, the present and speculations about the future. Am J Gastroenterol 1987, 82: 283-286.

7. Rathbone, B.J., Wyatt, J. \& Heatley, R.V. Campylobacter pyloridis - a new factor in peptic ulcer disease. Gut 1986, 27: 635-641.

8. Skander, M.P. \& Ryan, F.P. Non-steroidal antiinflammatory drugs and pain free peptic ulceration in the elderly. Br Med J 1988, 297: 833-834.

9. Lanza, F.L., Royer, G.L., Nelson, R.S. et al. The effects of ibuprofen, aspirin, naproxen and placebo on the gastric mucosa of normal volunteers. Dig Dis Sci 1979, 24: 823-828.

10. Collier, D.St.J. \& Pain, J.A. Non-steroidal anti-inflammatory drugs and peptic ulcer perforation. Gut 1985, 26: 359-363. 
11. Hawkey, C.J. Non-steroidal anti-inflammatory drugs and the gastric mucosa: mechanisms of damage and protection. Aliment Pharmacol Ther 1988, 2 (Suppl. 1): 57-64.

12. Ainley, C.C., Forgacs, I.C., Keeling, P.W.N. \& Thompson, R.P.H. Outpatient endoscopic survey of smoking and peptic ulcer. Gut 1986, 27: 648-651.

13. Massarat, S., Enschai, F. \& Pittner, P.M. Increased gastric secretory capacity in smokers without gastrointestinal lesions. Gut 1986, 27: 433-439.

14. McCready, D.R., Clark, L. \& Cohen, M.M. Cigarette smoking reduces human gastric luminal prostaglandin $\mathrm{E}_{2}$. Gut 1985, 26: 1192-1196.
15. Jones, D.M., Eldridge, J., Fox, A.J., Sethi, P. \& Whorwell, P.J. Antibody to the gastric campylobacter-like organism ('Campylobacter pyloridis') - clinical correlations and distribution in the normal population. J Med Microbiol 1986, 22. $57-62$.

16. Loffeld, R.J.L., Stobberingh, E., Flendrig, J.A., Van Spreeuwel, J.P. \& Apends, J.W. Diagnostic value of an immunoassay to detect anti Campylobacter pylori antibodies in non-ulcer dyspepsia. Lancet 1989, i: 1182-1185. 